\title{
新宿駅周辺地域を対象とした都心業務地域における 地域連携による危機対応とその標準化に関する研究
}

\author{
新藤 淳 $^{1)}$ 、村上正浩 ${ }^{2)}$ 、久田嘉章 ${ }^{3)}$ \\ 1)正会員 損保ジャパン日本興严リスクマネジメント株式会社、主任コンサルタント 修士(工学) \\ e-mail : jun.shindo@sjnk-rm.co.jp \\ 2)正会員 工学院大学建築学部まちづくり学科、准教授 博士(工学) \\ e-mail : murakami@cc.kogakuin.ac.jp \\ 3)正会員 工学院大学建築学部まちづくり学科、教授 工学博士 \\ e-mail : hisada@cc.kogakuin.ac.jp
}

\begin{abstract}
要 約
近年、大都市の中心市街地における共助の仕組みであるエリア防災が注目され、新宿駅周 辺地域においても、国の制度を活用して新宿駅周辺地域都市再生安全確保計画が進められ ている。その中で、西口現地本部は災害発生時の地域の中心的な活動拠点として位置づけ られている。本報では、国際標準に則った西口現地本部の機能、役割及び訓練の推進を目 的として、災害・危機対応に関する国際規格(ISO22320)を活用した検証を行なった。本研 究により、都市再生安全確保計画に基づくエリア防災活動を推進するにあたっての、課題 や今後の方向性を明確にすることが出来た。
\end{abstract}

キーワード：地域連携、エリア防災、地震防災訓練、ISO22320、都市再生安全確保計画

\section{1. はじめに}

\section{1 都心業務地域における地域連携による危機対応について}

新宿駅周辺地域は企業事務所や商業施設等が集積する我が国を代表する業務地区であり、新宿区 （2013）によると地域内の滞在者数は新宿駅西口の約 $1.7 \mathrm{~km}^{2} の$ 範囲にピーク時で約 18.1 万人に達する。東 日本大震災の発災時には地震による直接的な被害は限られていたものの、主要鉄道が機関の運行停止に より大量の帰宅困難者が発生し、固定電話・携帯電話等が輻輳して通信機能が著しく低下したことによ り大きな混乱が発生した。なお、首都直下地震等の大規模地震が発生した場合には、上記と同様かそれ 以上の状況が発生することに加え、建築物等の損害や電気・ガス・水道等のライフライン関連施設等へ の直接的な被害や大量の傷病者の発生などが想定され、地域に立地する企業や商業の業務継続が困難と なることが予想される。

このような、都心業務地域における地域防災力の向上にあたっては、地域の諸関係者による協力・連 携による地域ぐるみの活動が重要であることが指摘されている(例えば、西川 (2012))。その実践的な事 例としては、東京駅周辺の大手町・丸の内・有楽町地区や新宿駅西口地域等が先駆的な取り組みとして 
知られており、現在では全国各地で各地域の特徵を踏まえた取り組みが行われている。

なお、災害時に地域の関係団体が協力・連携して災害対応にあたる場合には、関係者間での情報共有 や各種の調整を行う拠点の役割が重要となる。しかし、特定の組織が設置する災害対策本部等の役割に 関する報告は多いものの、複数の企業・団体等が臨時に設置して運営する拠点の役割や活動に関する報 告は知られていない。

\section{2 新宿駅西口周辺地域における既往の取組について}

新宿駅西口周辺地域（以下、「西口地域」とする。）では、2007年6月に東京都の駅前滞留者対策のモ デル事業として、新宿駅周辺滞留者対策訓練協議会 (2009年4月に改称して、現在は新宿駅周辺防災対策 協議会)が設立され、地域連携の取組みとして情報収集・伝達、医療連携、建物安全確認、セミナーの開 催による地域の人材育成、継続的な訓練の実施による検証等の様々な活動が行われており（既報としては、 村上・久田(2010)、児島(2011)、Masuzawa et al.(2014)等)、筆者は事務局として主に西口地域を管轄する 部会の運営の一端を担っている。

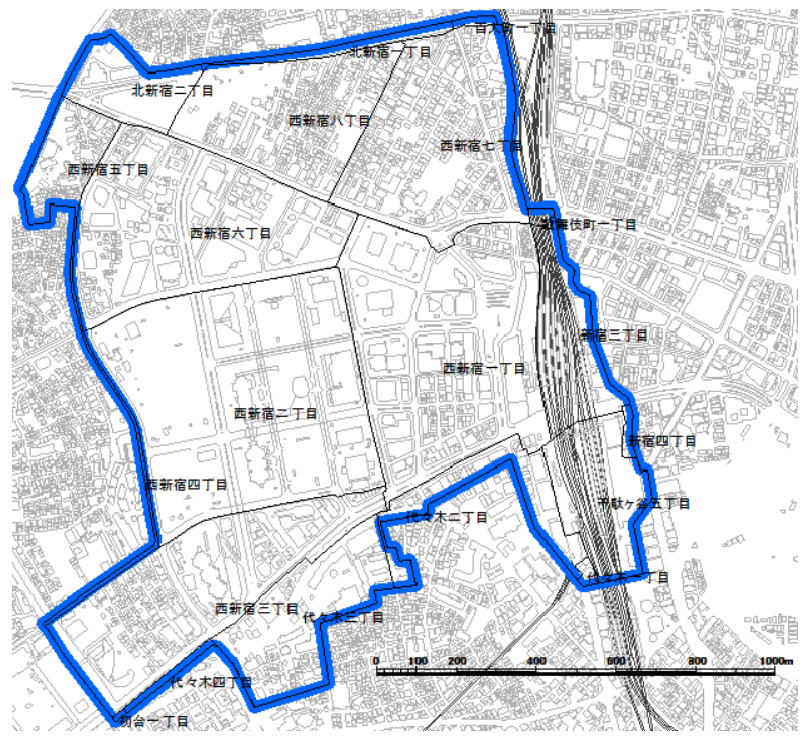

図 1 新宿駅西口地域の範囲図（新宿区(2013)より)

また、2013年度にはそれまでの活動の成果を踏まえ、前年に国が創設した都市再生安全確保計画制度 に基づき、新宿駅周辺地域の都市再生安全確保計画(以下、「同計画」とする。)が策定された。同計画 は、新宿駅周辺における上述の取組を体系的に整理し、大規模災害発生時の滞在者の安全確保及び立地 企業等の事業継続性の確保等のあり方を示した「新宿モデル」を実現するために定められた。同計画の 基本計画西口編では、大規模災害時に西口現地本部が設置され情報収集・伝達を中心に地域内の事業所 が協力・連携して活動する際の拠点として位置づけられている。西口現地本部では、果たすべき3つの機 能が定められ、各機能の実施のための運営マニュアルが策定されており、マニュアルに沿った訓練が行 われ内容の更新が図られているが、実際の災害時に実効性をもった対応を行うに十分な内容か否かにつ いては、いまだ検討の余地がある。また、西口現地本部は、多様な地域内の関係団体の協力・連携の拠 点となることが期待されているため、関係団体間で円滑な災害対応を行うにあたり帳票類や対応手順等 について国際規格（IS022320）に基づく標準化が必要と考えられるが、西口現地本部の活動に対してその ような視点からの検証はなされていない。

\footnotetext{
${ }^{1}$ 都市再生安全確保計画制度とは、都市再生特別措置法に基づき、官民からなる都市再生緊急整備協議 会が、大規模地震発生時における滞在者等の安全の確保を図るために作成する都市再生安全確保計画と その計画に基づき運用される諸制度の総称。(内閣府(2015)をもとに加筆）
} 


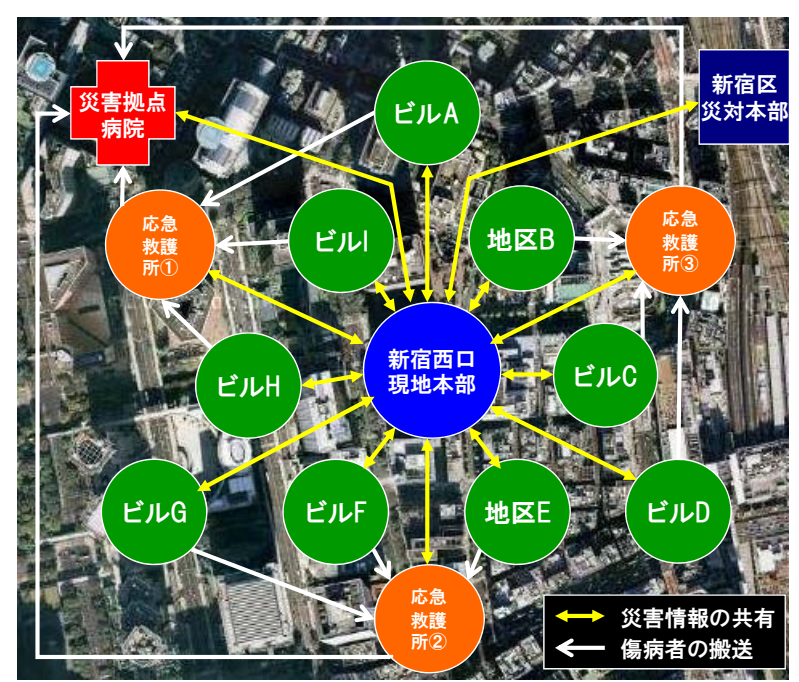

図 2 新宿西口現地本部を中心とした地域連携のイメージ（新藤他 (2012)より)

\section{3 目的}

本報では上述した背景を踏まえ、西口地域を都心業務地域のモデルとして位置づけ、地域の関係機関 の協力・連携の拠点としての現地本部の機能や役割を及び今後必要となる取り組みについて明確にし、 西口地域での取り組みを海外も含む他の地域へ適用することを目的とする。

そこで、まず現状における西口現地本部の取り組みにおける課題や問題点を明確にするため、2013年 度に実施した訓練結果と得られた課題について報告する。次に、他地域においても適用可能とするため、 現地本部に対して標準的に求められる機能や対応手順等を、危機対応に関寸る国際規格と現在の西口現 地本部に関する取組みを比較することで明確にし、今後の取り組みの方向性について示す。

\section{2. 新宿駅西口周辺地域における危機対応}

\section{1 西口現地本部の機能と役割}

\section{(1)西口現地本部の概要}

大規模地震等が発生した場合、新宿駅西口地域において多数の傷病者が発生するとともに、帰宅困難 となる事業所役職員や来街者が多数発生することが想定される。また、公共交通機関の運行停止に伴い 新宿駅周辺は多くの滞在者で混乱する恐れがある。さらに災害の規模により、近隣地域からの避難者の 流入や、地下街や高層ビル内の飲食店からの同時多発的な火災発生の可能性も否定できない。しかし発 災直後においては、自治体や警察・消防などの行政機関は、多数の被災者の救命救助をはじめとする災 害対策活動に従事せざるを得ず、個々の事業者への支援には限界がある。

そこで、西口地域全体の災害対応力を向上させるため、西口地域の事業者が必要な情報を共有し、連 携・調整して効率的な災害対応活動を行うとともに、地域内の滞留者等への情報提供を担う拠点として 西口現地本部が置かれることとなった。なお、現行の西口現地本部運営マニュアルでは、西口現地本部 は23区内で震度 5 強以上の地震に見舞われた際等に、工学院大学新宿キャンパスに設置されることが定 められている。なお、西口現地本部の運営者については名簿等で明確には定められてはおらず、地域の 企業・団体から現地本部設置場所に参集したものが立上げ、運営することが想定されている。

\section{(2)西口現地本部の機能}

西口現地本部は、2007年に東京都のモデル事業として実施した駅前滞留者対策訓練の際に、地域事業 者及び駅前滞留者との情報共有・発信の拠点を主な機能として設置され、毎年実施される訓練を通じて その機能や活動内容の見直しがなされている。

現在の西口現地本部は、1)駅周辺事業者の情報交換拠点、2)地域の応急救護の情報拠点、3)地域の災害 
対応活動の支援拠点の大きく3つの機能を担うとされており、各機能を果たすための運営マニュアルが作 成され、訓練結果等を踏まえて継続的に更新されている。西口現地本部の機能の概念図は図 2 を参照の こと。

\section{1 ）駅周辺事業者の情報交換の拠点}

駅前の混乱を最小限に留めるとともに、滞留者を適切に誘導するため、事業所内職員等の一斉帰宅 行動を抑制するとともに、買物等での来街者や移動中にたまたま居合わせた者等の身の寄せどころの ない滞在者を適切な場所へ誘導する。そのために必要な、滞留者に提供する情報の交換を行う。

\section{2 ）地域の応急救護の情報拠点}

「自助」で対応できない傷病者を搬送する場合に必要となる適切な情報を提供するため、地域の応 急救護拠点や近隣の災害拠点病院の情報(受入の可否、受入条件、活動状況)を収集・整理し、各事業 所に提供する。

\section{3 ）地域の災害対応活動の支援拠点}

地域の事業所における災対活動の円滑な実施を支援するため、各事業所及び現地本部等の活動拠点 における専門家、ボランティア要員及び資機材等の過不足を把握し、優先順位を判断し調整を行う。

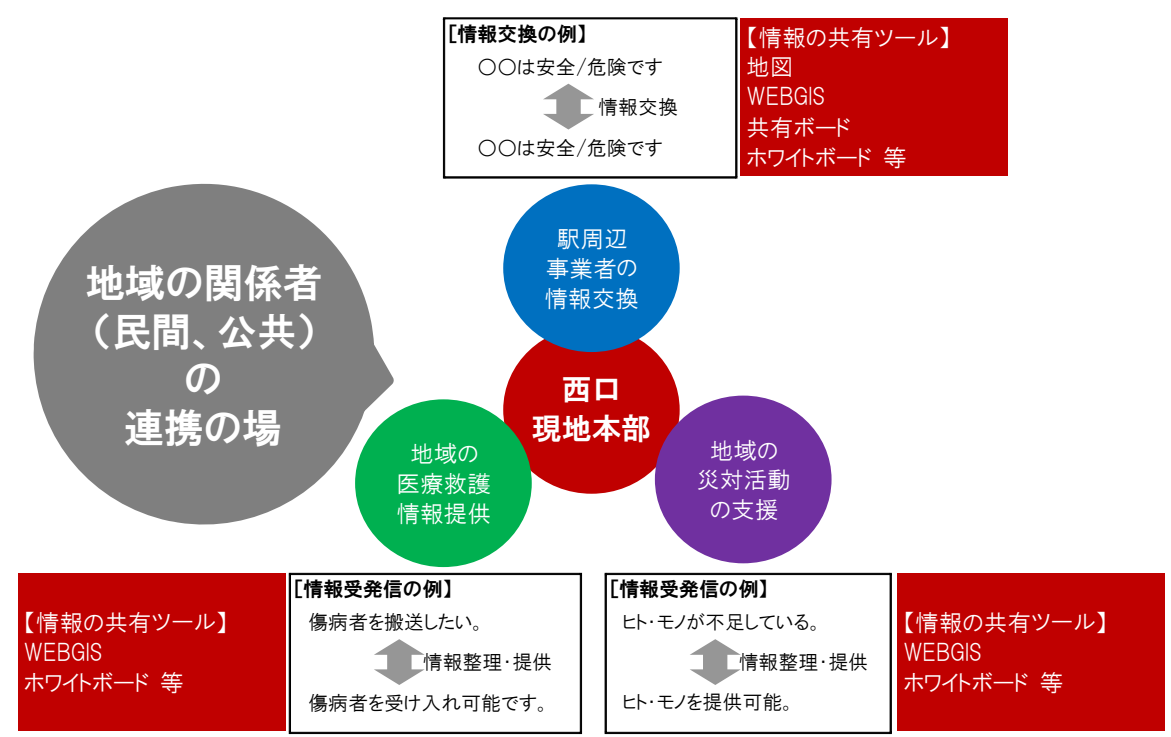

図 3 西口現地本部の機能

\section{2 2013年度西口現地本部訓練}

2013年度西口現地対策本部訓練は、筆者らが中心となり企画・運営を行い2013年11月7日に実施された。 訓練には、地域の企業及び行政機関から7名が参加して行われた。訓練では、発災数時間後の場面を想定 し、西口現地本部を中心に関係機関等との情報連絡やエリア内での情報共有を行い、西口現地本部の役 割と現地本部を運営するためのマニュアル等を検証した。

なお、訓練の実施にあたっては、東京湾北部地震(マグニチュード7.3)の発生を想定した。駅周辺事業 所及びその周辺の被害の状況等については、個別に定め状況付与票としてとりまとめ、訓練時に配付し た（図 5 参照）。なお、各事業所から現地本部への伝達は、伝令によるものと想定した。

前述のとおり、西口現地本部には「駅周辺事業者の情報交換の拠点」、「地域の応急救護の情報拠点」、

「地域の災害対応活動の支援拠点」の3つの機能がある。そこで、訓練は大きく前半と後半に分け、前半 の訓練では、「駅周辺事業者の情報交換の拠点」としての役割を検証した。後半の訓練では、「地域の 応急救護の情報拠点」および「地域の災害対応活動の支援拠点」としての役割を検証した。訓練時にお ける関係機関からの情報の流れについては図 4 及び図 6 を参照のこと。なお、当日の訓練の流れは次の とおりであった。 
表 1 当日の訓練の流れ

\begin{tabular}{|c|c|c|}
\hline 時間 & & 訓練実施内容 \\
\hline $13: 00 \sim 13: 30$ & \multicolumn{2}{|r|}{ 参加者集合(13:00)、訓練内容·役割の確認 } \\
\hline $13: 30 \sim 14: 00$ & \multicolumn{2}{|c|}{ 使用機器類の確認 } \\
\hline $14: 00 \sim 14: 15$ & \multirow[b]{2}{*}{$\begin{array}{l}\text { 剪 } \\
\text { 半 }\end{array}$} & 訓練開始(14:00)、関係機関·現地本部等の活動状況の把握 \\
\hline $14: 15 \sim 15: 00$ & & $\begin{array}{l}\text { 被害情報の共有、帰宅困難者の受入情報等の共有、帰宅困難者への受入情報 } \\
\text { 等の提供 }\end{array}$ \\
\hline $15: 00 \sim 15: 15$ & \multirow{4}{*}{$\begin{array}{l}\text { 後 } \\
\text { 半 }\end{array}$} & 状況確認、調整 \\
\hline $15: 15 \sim 15: 25$ & & 高層ビルへ建築専門家·ボランティアの派遣 \\
\hline $15: 25 \sim 16: 05$ & & 区内医療機関情報の共有、緊急医療救護所 (仮)の支援 \\
\hline $16: 05 \sim 16: 15$ & & 高層ビルの被害情報の共有、訓練終了(16:15) \\
\hline $16: 30 \sim 17: 30$ & \multicolumn{2}{|c|}{ 講評会 } \\
\hline
\end{tabular}

前半は、新宿区との協定に基づいて、工学院大学新宿キャンパス1階アトリウムの一角に西口現地本部 の開設宣言を行う場面から訓練を開始した。本部長・副本部長の指示のもと、帰宅困難対策班は、新宿 区災害対策本部・角筈地域本部の活動状況や地震情報に加え、新宿駅の鉄道情報や新宿駅周辺の道路情 報・火災情報・滞留情報、新宿中央公園・新宿御苑の滞留情報等を把握した。情報収集・発信担当は、 東口現地本部や近隣高層ビルの活動状況等を確認しつつ、状況付与票や広域情報共有システム、災害時 ビル情報入力システム等を用いて、近隣高層ビルの被害情報や、新宿駅周辺および広域の被害情報等を 確認した。これらの情報は、情報整理・集約担当が集約し、必要な情報を抽出したうえで、ホワイトボ ードや紙地図に書き出していった。そして、情報共有担当は、ホワイトボードや紙地図に書き出した情 報を、広域情報共有システムに入力し、新宿区災害対策本部と共有した。
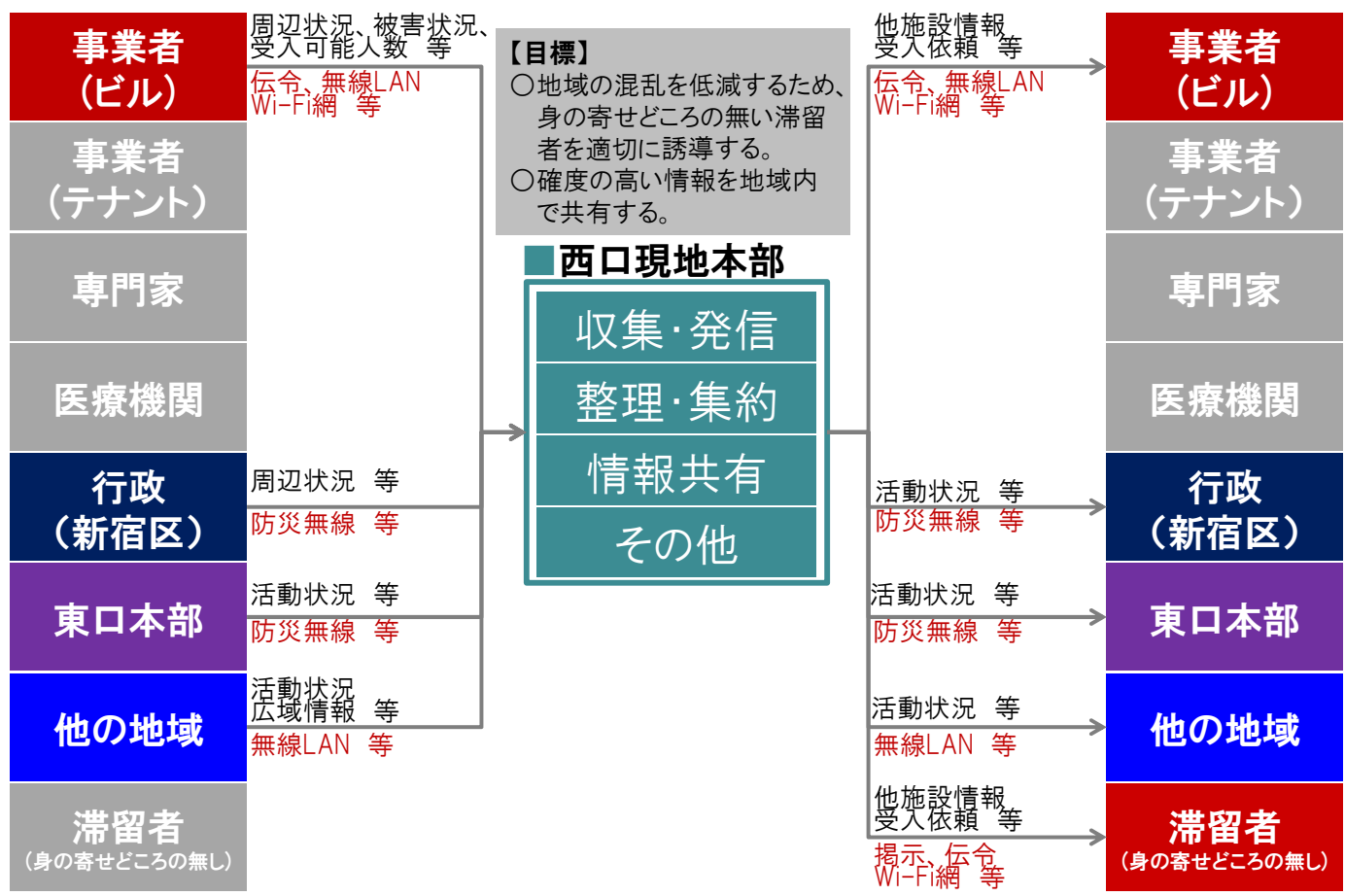

（訓練前半）駅周辺事業者の情報交換の拠点としての役割 図 4 訓練における情報の流れ等 


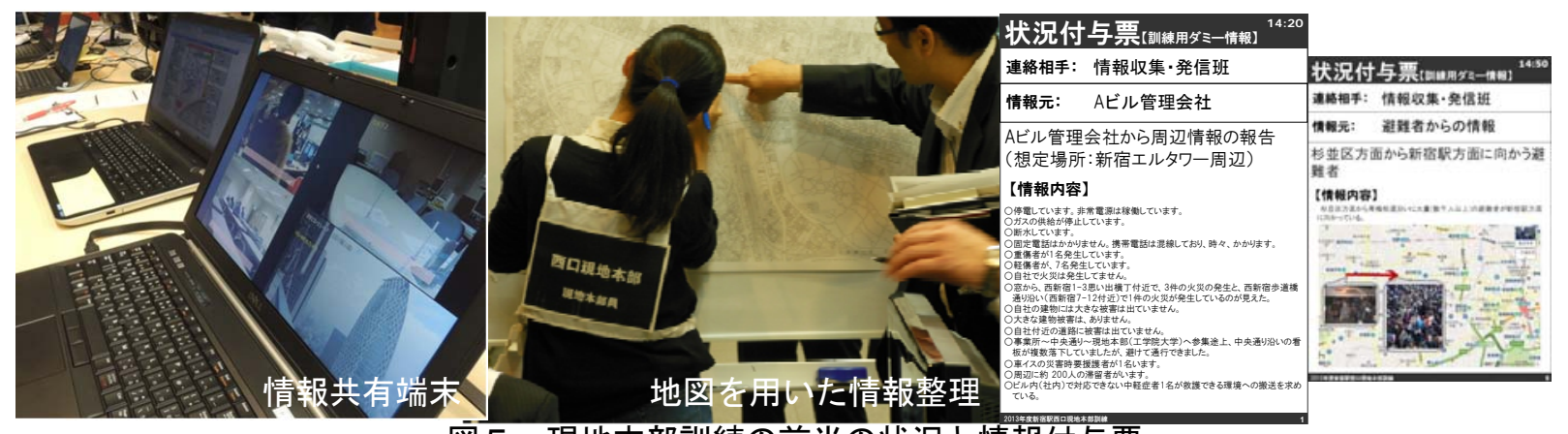

図5 現地本部訓練の前半の状況と情報付与票

後半では、新宿駅西口地域の災害対応を支援するために建築専門家や学生ボランティアが西口現地本 部へ参集し、情報収集・発信担当が到着時刻・所属・氏名等を記録した。本部長は、建築専門家や学生 ボランティアに対して、前半の訓練で集約した高層ビルの被害状況や高層ビルからの支援要請内容を説 明したうえで、被害が多数発生している高層ビルや支援要請があった高層ビルへ建築専門家・学生ボラ ンティアを派遣した。情報整理・集約担当は、建築専門家・学生ボランティアの派遣先等をホワイトボ ードへ書き出し、情報共有担当がそれらを広域情報共有システムへ入力した。また、帰宅困難者対策班 は、防災行政無線を使って、建築専門家や学生ボランティアの派遣情報を新宿区災害対策本部へ報告し た。

一方、新宿区災害対策本部と情報連絡をとりながら、仮想の緊急医療救護所からの要請に基づいて災 害拠点病院での重症者の受入情報や不足資機材の提供情報等も入手し、緊急医療救護所へ情報提供した。

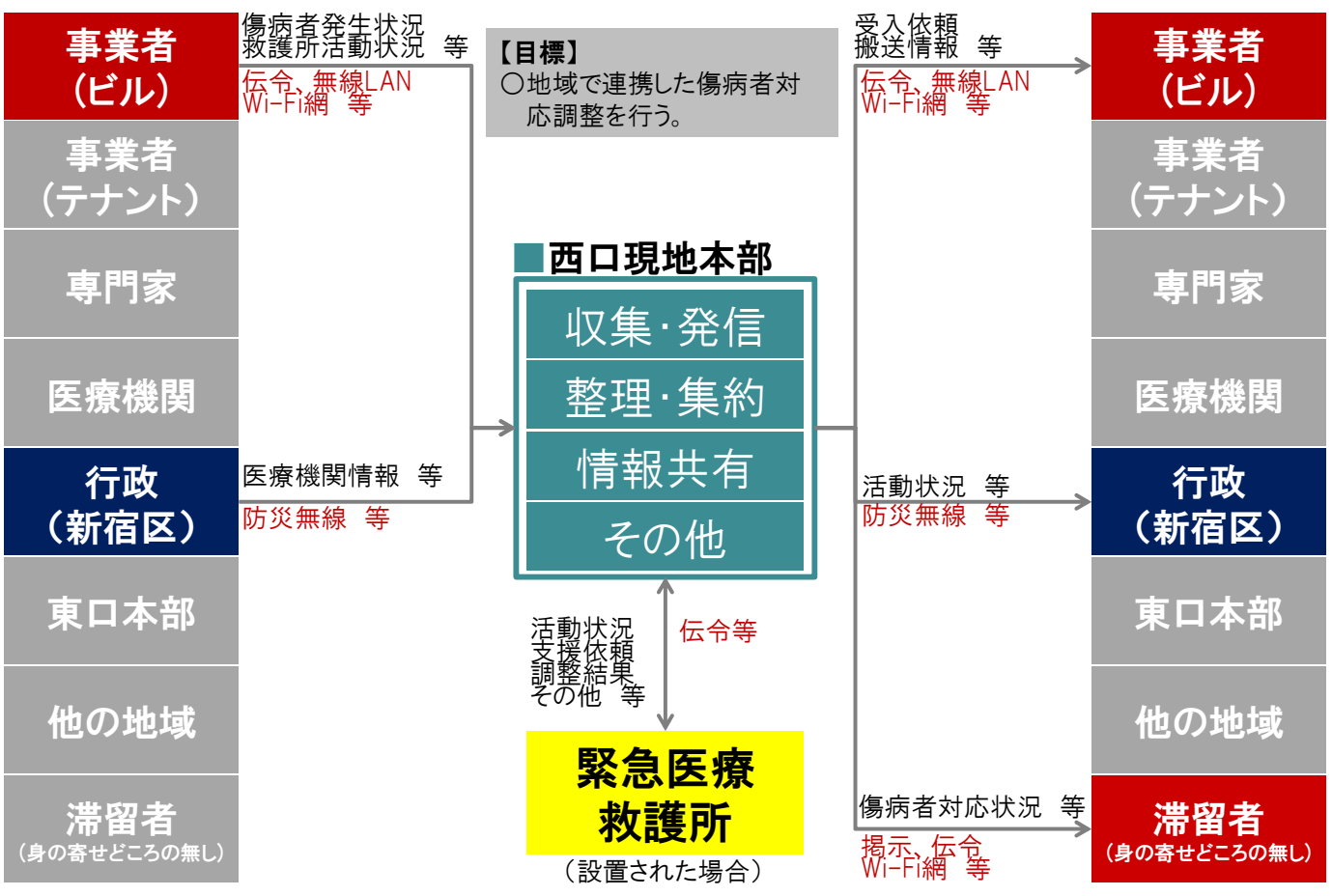

（訓練後半）地域の応急救護の情報拠点としての役割

図 6 訓練後半における情報の流れ等 $(1 / 2)$ 


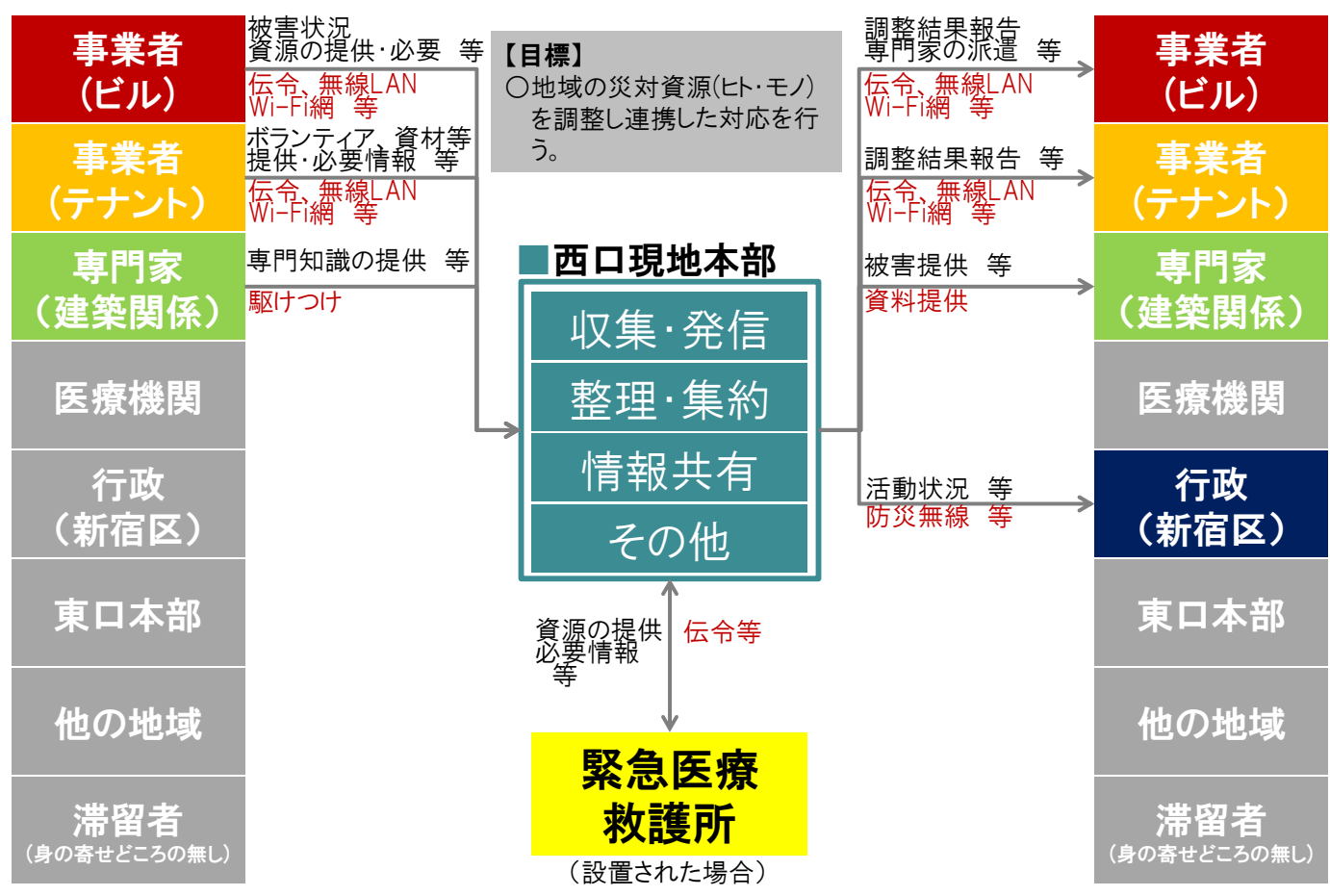

（訓練後半）地域の災害対応活動の情報拠点としての役割

図 7 訓練後半における情報の流れ等 $(2 / 2)$

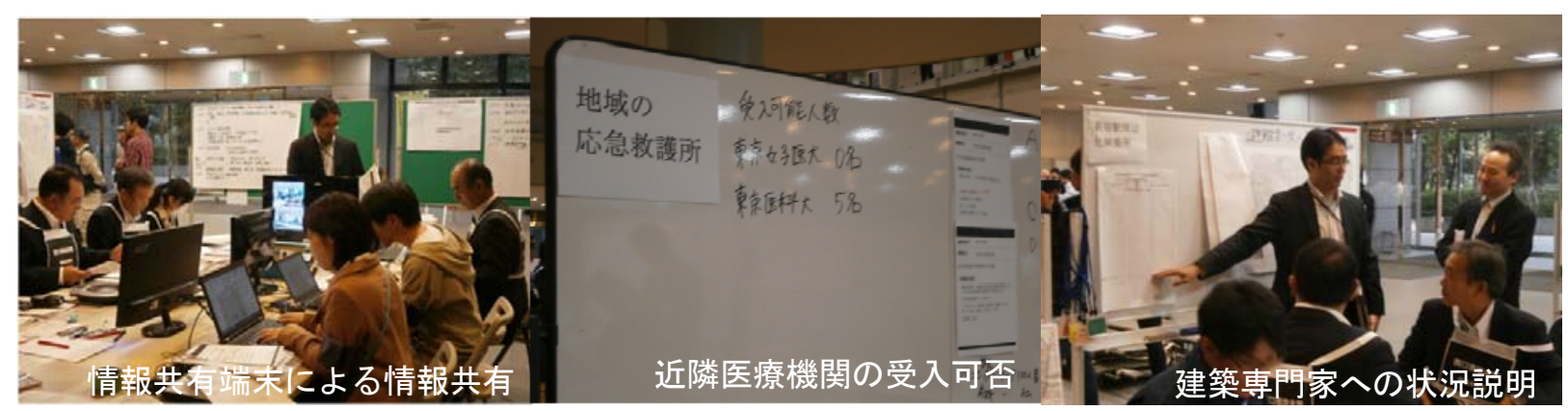

図 8 西口現地本部訓練の後半の状況

\section{3 2013年度西口現地本部訓練による課題と要改善点}

西口現地本部訓練後には訓練参加者による意見交換を行い、訓練結果を共有し要改善点について議論 が行われた。意見交換会を踏まえた西口現地本部における取組の課題や要改善点は次のとおりである。

\section{(1)通信機材関係}

・機材の使い方が分からない参加者が多かった。使用する機材の説明を現地本部運営マニュアルに入れ る必要がある。

・各種の通信機材にどのような特徵があり、どこと連絡を取る場合に適しているかが分からない参加者 が多かった。どの連絡先と何を使って連絡できるのかを整理して、本部内で共有する必要がある。

・今回訓練では現地本部の設営等は事前に行ったが、実際には現地本部設置場所に参集した者が設営か ら始めることになる。現地本部で使用する機材の保管場所等を現地本部運営マニュアルに反映する必 要がある。 


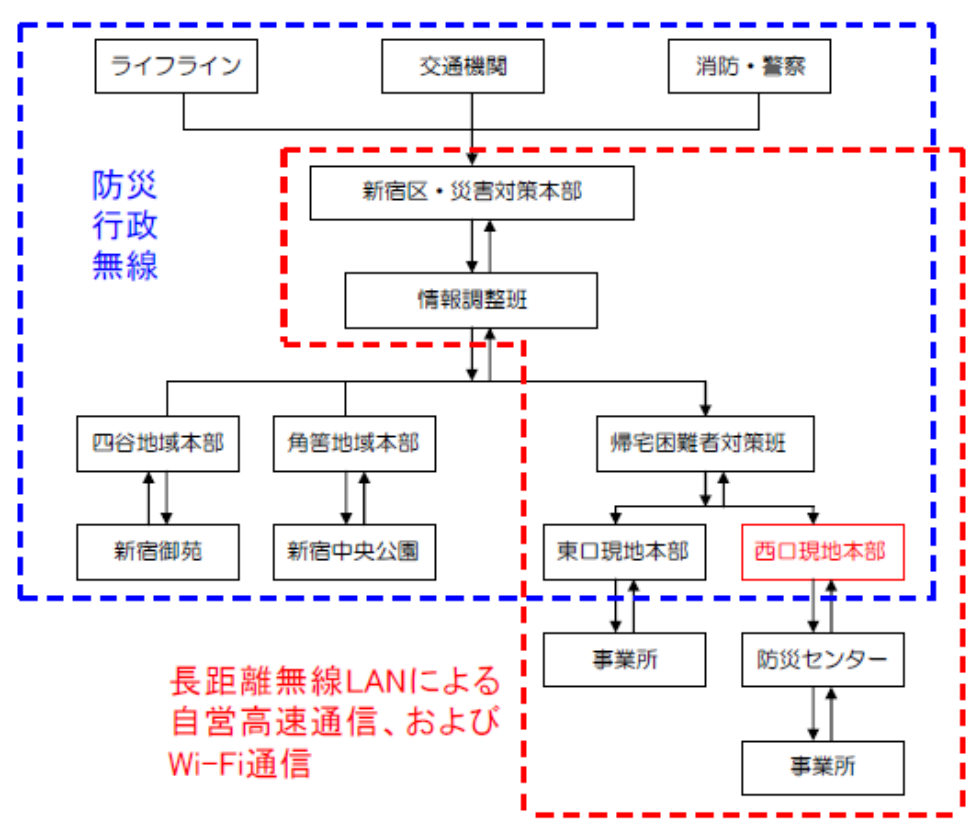

図 9 西口現地本部関係の連絡網と使用する通信機器

\section{(2)現地本部の活動について}

・現地本部の活動要員はあらかじめ定まっておらず、参集可能な要員が本部を立上げて活動を開始する ことになる。訓練ではあらかじめ参加者に役割を割り振ったが、より現実的な対応を想定すると、活 動開始時に、各自がじのような役割を行なうのかを指示・確認する必要がある。

・現地本部が入手する情報について、より梁く分析し整理するためには、現地本部の活動要員はある程 度、他の関連する取組み（建物被害対応、応急救護活動）の概要を理解しておく必要がある。

\section{(3)情報の整理方法等について}

・訓練時にはホワイトボードに時系列で情報を整理したが、その後に入手した情報との関係が分からな くなってしまった。段階的に詳細情報が入手されることなどを想定し、番号を振るなどして既に入手 した情報との紐付けが出来るようにする必要がある。

・よく用いる言葉・用語については、略語を定めて共有しておくことが望ましい。

・救護所と現地本部の間の情報交換については様式が定められておらず口頭で伝えられたが、現地本部 では多種多様な情報を扱っているため、何処からの何に関する情報なのか十分に理解できなかった。 事前に想定できる情報については、様式を定め関係者間で共有する必要がある。

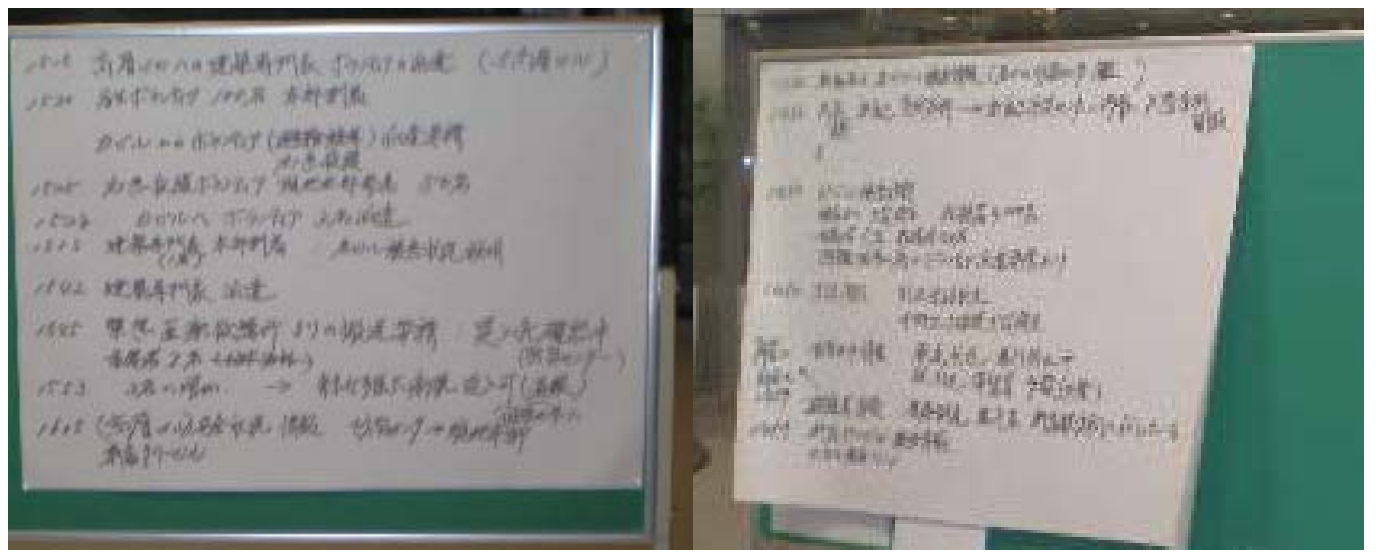

図10＼cjkstart西口現地本部訓練において情報を時系列で整理した例 


\section{(4)現地本部の設置場所}

・今回訓練では、工学院大学 1 階アトリウムの片隅に現地本部を設置したため、訓練時には本部内で互 いの声が聞き取りにくかった、設置場所や本部レイアウトについては改めて検討する必要がある。

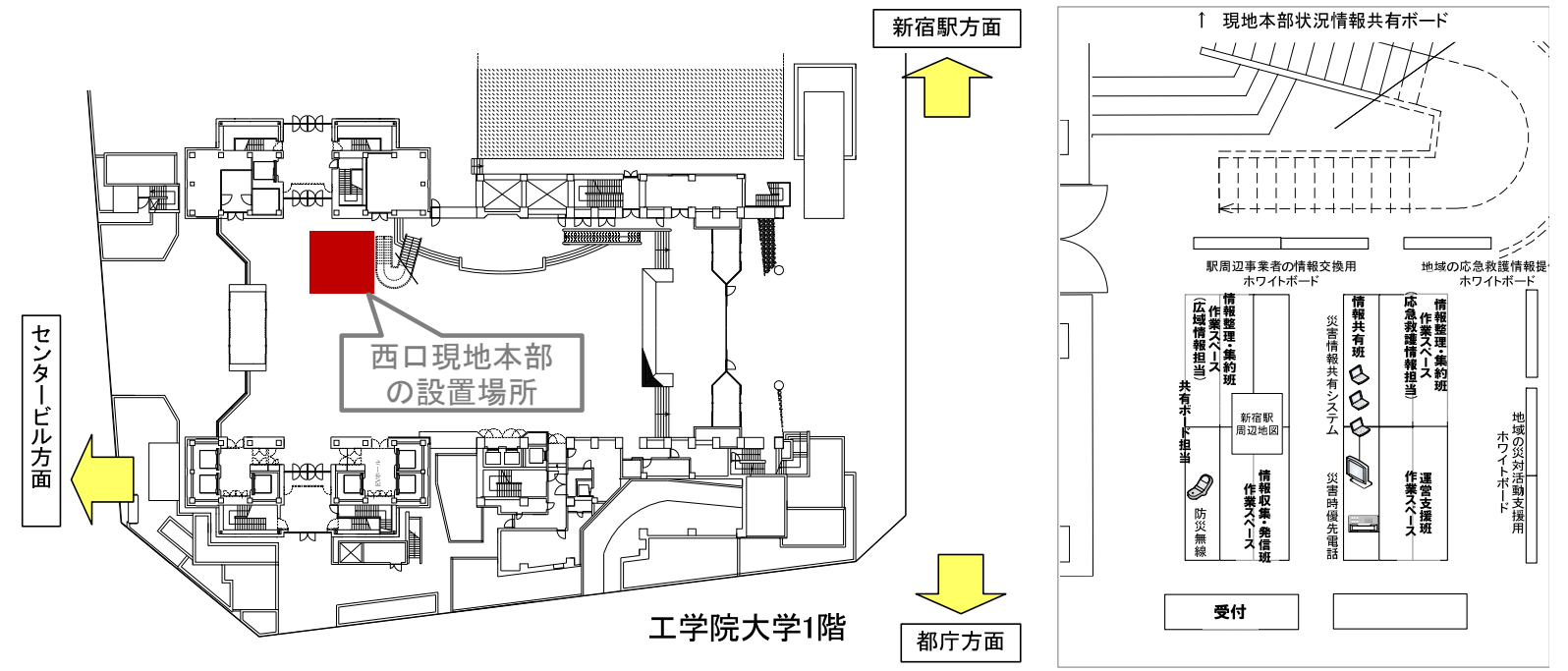

図11＼cjkstart現地本部の設置場所と本部レイアウト図

\section{3. 西口周辺地域の活動と国際標準化の取組み}

\section{1 IS022320:2011について}

ISO22320:2011とは、2011年に第一版として発行された社会セキュリティ-緊急事態管理-危機対応に関 する要求事項を定めた国際規格であり、その邦訳に当たる規格が2013年10月にJIS Q 22320 として日本規 格協会より発行された。本規格は大きく「4 章 組織内指揮統制」「5 章 活動情報処理」「6 章 組 織間協力連携」で構成されており、国際レベル、国家レベル、地域レベル又は地方レベルで危機対応に 関するあらゆる組織(民間、公的、政府系又は非営利)に適用できるとされている。なお、本規格は全6章 であるが、 1 章は適用範囲、 2 章は引用規格、3 章は用語及び定義であり、要求事項は記載されていな い。

\section{2 国際規格を用いた西口現地本部の活動の検証}

\section{(1)検証方法}

本研究では主に2013年度訓練実施時点での西口現地本部の活動を中心に、ISO22320:2011（以下、「本 規格」とする。）における要求事項(規格において「〜ねばならない」と記述されている事項 [計51箇所]) と比較し、規格の求める基準に沿った活動が行われているか否かを確認することで、西口現地本部の活 動が標準的なレベルに達しているかを評価した。評価は、1)適合(要求事項を満たしている)、2)概补適 合(一部満たしていない部分があるが、要求事項の大半を満たしている)、3)一部適合(要求事項を満たし ているとは言えないが、一部満たす事項がある。)、4)不適合(要求事項を満たしていない)の4段階で行っ た。また、西口地域に適さない事項については「適用外」とした。なお本規格の要求事項は、国際規格 として十分に審議されて発行されていることから、客観的な判断が可能な表現となっているが、規格の 性格上定性的な記述であるため、評価者によってある程度の解釈の違いが発生し得る。今回の評価は、 筆頭著者がまず評価し、その後に共著者2名が確認を行うという形で、3名の評価者による合議の形で行 った。

全51項目の要求事項に対する西口現地本部の活動の検証結果は、巻末の付録に示した。

検証結果を主要 3 章別に比較すると、指揮・統制( 4 章)については、比較的要求事項を満たしている 事項が多いが、活動情報 ( 5 章)、協力連携( 6 章)については、不適合事項が多く今後の改善の余地がある。 
これは、「指揮・統制」で挙げられている事項については、訓練等での検証が行いやすく過去の取り 組みにおいて改善がなされているが、「活動情報」「協力連携」については、限られた条件での訓練で は検証を行うことが難しく、顕在化していなかった課題が浮かび上がったものと考えられる。

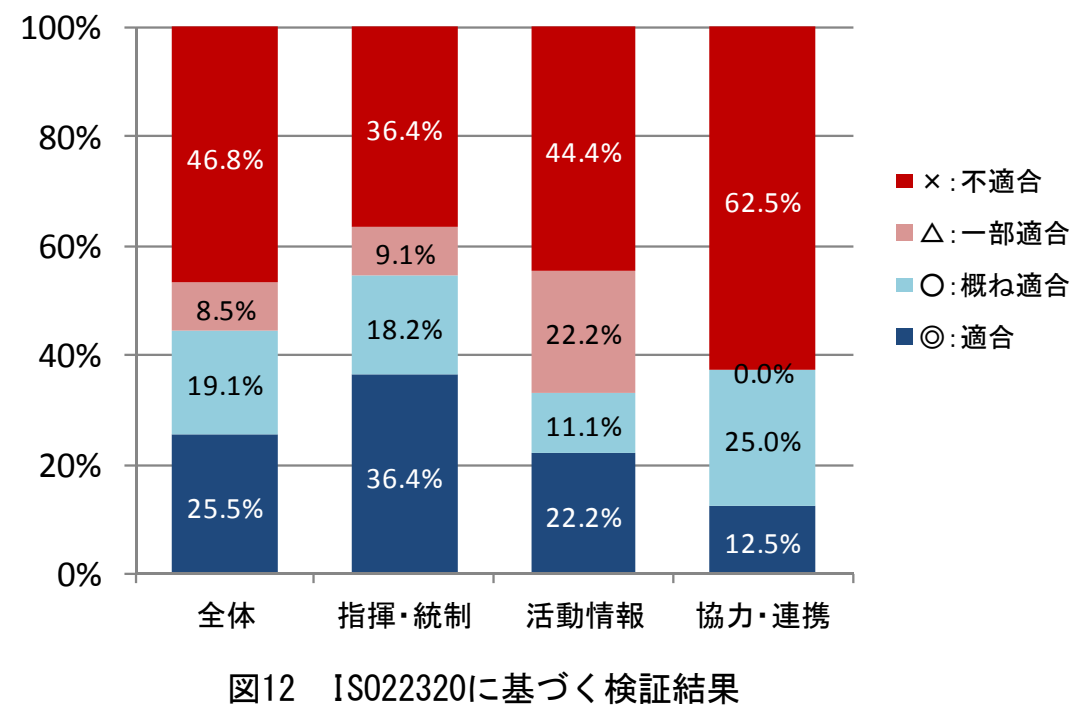

\section{(2)主な検証結果}

主要な要求事項に対する評価を次に示す。なお、本文中の【】内の番号及び付記した見出しは、対応 する本規格の「箇条」と「見出し」である。

\section{【4. 1 指揮・統制に関する要求事項 一般】}

(1)本規格では指揮・統制に含まれる10の任務を挙げた上で、危機対応の任務にふさわしい権限付与と 各種資源の用意を求めている。西口現地本部に与えられた危機対応の任務にふさわしい権限がどの ようなものかについては明確ではないことから「不適合」とした。また、組織内において「本部長」

「リーダー」等の役割を設定しているが、それらの役割がもつ権限も明確ではない。危機対応の任 務にふさわしい各種資源については、訓練時に想定されている物的資源は十分ではあるが、各種資 源があらかじめ定められた場所に備蓄されてはおらず、訓練時に随時集めているほか、現地本部の 設置場所も公式に定めらえてはいない。人的資源についても、事前に活動要員が定められてはない。

(2)本規格では、危機対応策の策定及び実施にあたり、地域社会の参画を促すことを求めている。西口 地域においては、危機対応策の策定及び実施にあたり、新宿駅周辺防災対策協議会西口部会及びそ の幹事会において協議等を行ない危機対応策の検討を行ており、地域社会の参画がなされているこ とから、「適合」とした。

\section{【4.2. 1 指揮・統制システム 一般】}

(1)本規格では、5つの要件を挙げてこれらを満たす指揮・統制システムの構築を求めており、システム の構築にともないリーダーとしての責任を担える人々の任命を求めている。西口現地本部における 指揮系統としての指揮・統制者は、西口現地本部に集まった人の中で選任することが定められてい ることから、「概ね適合」とした。

(2)本規格では、組織体制や指揮・統制システムに関するプロセスを文書化することを求めている。西 口地域ではこれらが「現地本部運営マニュアル」として文書化されていることから「適合」とした。

\section{【4.2.3 指揮・統制体制】}

(1)本規格では、指揮・統制体制を「判断の種類」や「時間的な枠組み」に応じて、”戦術レベル”、” 作戦レベル”等のレベル別に分けることを求めている。西口現地本部で想定される活動については、 情報の収集や提供等の現場レベル(戦術レベル)の活動と、地域の資源の融通や調整等の戦略レベル の活動が混在しており、レベル別に分かれているとは言えないことから、「不適合」とした。 


\section{【4.2.4 危機レベルへの対応】}

(1)本規格では、インシデントをその重要性に応じて幾つかのレベルに分類することを求めている。西 口地域での取組みでは、過去の訓練等で想定しているインシデントは地震のみであることから、「不 適合」とした。ただし、現地本部の設置基準については、あらゆるインシデントに対応できる一般 的な基準を設けている。

\section{【4. 3 人的要因】}

(1)本規格では、危機対応活動は当該文化に受け入れられる形で被災者の要望に沿って実施することを 求めている。西口地域では、部会、セミナー、連携訓練等の活動を通じて地域の人々との議論の中 で、文化や要望を把握し様々な活動にフィードバックしていることから「適合」とした。

(2)本規格では、「作業分担」「安全・衛生」「要員の交代」「人・機械・システム間のインターフェ イス設計」の 4 つの人的要因を挙げ、適切な処置を講じるよう求めている。西口地域では、訓練を 通じてこれらの人的要因の検証をおこなっているが、その結果に対して過去の訓練を踏まえて適切 な処置が行なわれているとは言えないことから、「一部適合」とした。

(3)本規格では、危機対応に関与する全ての人が全体の業務体制のどこに自身が位置づけられているか を理解し、教育訓練等を通じて適切な力量を備えることを求めている。西口地域では、セミナーや 訓練を通じて、業務体制の中での位置づけや資源を使いこなす力量の向上を図っていることから、

「適合」とした。

\section{【5.2.3 活動情報2に関する要求事項 情報収集】}

(1)本規格では、3つの活動を挙げ情報収集活動に含めることを求めている。西口地域では、「情報源の 確認」「情報の取得」についての活動が行われていることから「概ね適合」とした。ただし「情報 源及び入手時刻の特定も含め入手した情報の登録及び記録」については明確なルールが定まってい ない。

\section{【5.2. 4 情報の処理及び利用】}

(1)本規格では、「a)効果的な発信をするために適切な書式への情報の適合」から「e)情報の信憑性の 評価」までの 5 つの活動を求めている。西口地域においては、「信憑性の評価」や「無用・不正確 等の情報の排除」などについて、明確なルールが定まっていないことから、「不適合」とした。ま た訓練において情報の取捨選択が必要となるレベルの情報付与等は過去に行われていない。

\section{【5. 2.5 情報の分析及び作成】}

(1)本規格では、情報の分析及び作成にあたり「指揮・統制者の優先要求事項や依頼を満たす事」を求 めている。西口地域では、指揮・統制者のもとで情報を分析作成することが想定されており、規格 が求める指揮・統制者の依頼を満たすものと考えられることから、「適合」とした。

(2)本規格では、この段階で必要となる6つの活動を含めることを求めている。西口地域では、「優先順 位付け」、「照合」、「予想される結果の推定・推論」等については、明確なルールが定まってい ないことから、「一部適合」とした。

\section{【6.1 協力及び連携に関する要求事項 一般】}

(1)本規格では、協力及び連携に関して必要とされる相互間での協力が示されている。西口地域では、 西口現地本部を設置する新宿駅周辺防災対策協議会と、危機対応時に協力・連携が想定される関係 機関との間の協定等は締結されていないことから、「不適合」とした。(ただし、東京都と同協議会 との間で帰宅困難者対策協定が締結されている。)

\section{【6. 2 協力】}

(1)本規格では、協力時に組織に求められる4つの事項が示されている。西口地域では、西口現地本部を 関係組織間の協力・連携の場であると考えると、「協力協定の締結」及び「自組織の指揮・統制プ

2 「活動情報」とは、英語の“intelligence”が「諜報」という意味をもつことから、この意味を含まないこ とを明確にするために、本規格で用いられた造語である“operational information”の邦訳。 
ロセスへの参加」を除いて、規格の求める活動を満たしていることから「概ね適合」とした。

\section{【6.3.2 連携プロセス】}

(1)本規格では、関係組織間での複数の階層構造をもつ指揮・統制プロセスの構築が求められている。 西口地域では、複数の階層構造をもつ指揮・統制プロセスは構築されてはいないことから、「不適 合」とした。

(2)本規格では、(1)に関して既存の協力協定を尊重する事を求めている。西口地域では、既存の協力協 定等は特に存在しないことから、「不適合」とした。

(3)本規格では、連携における指揮・統制プロセスでの自組織に影響する方針等の決定への参画を求め ている。西口地域では、関係する団体の間で他の組織が別組織の意思決定に参加することは前提と してはいないことから「適用外」とした。ただし、平常時の取組みについては、西口部会や幹事会 等において意思決定に参加することができる。

(4)本規格では、連携における指揮統制プロセスにおいて、現場での早期の連携及び参画を含めるよう 求めている。西口地域では、関係組織が西口現地本部以外の場所で連携することは一部を除き想定 されてはいないことから、「適用外」とした。なお、現地本部においては、危機発生後早期に本部 に参集した要員間で連携することが想定されている。また、西口現地本部における各種の手続き等 の決定にあたっては、西口部会や幹事会等での検討を通じて定めることを前提としているため、参 画の機会及び公平性確保の機会は確保されている。

\section{【6.3.3 連携の目的】}

(1)本規格では、連携の目的を明確にし、かつ優先順位付けを行うことが求められている。西口地域で は危機対応時の連携の目的や優先順位付けについては明確になっていないことから、「不適合」と した。

(2)本規格では実際の危機対応活動に関して11項目の連携目的及びその適用可能性の評価が求められて いる。しかし、西口地域ではこのような評価は行われていないことから、「不適合」とした。

\section{【6. 5 人的要因】}

(1)本規格では、協力及び連携の組織体制等の規程及び設計にあたり人的な能力レベル等への配慮を求 めている。西口地域では協力及び連携の組織体制、システム及び機器の仕様の規定及び設計にあた っては、西口部会・セミナー・連携訓練を通じて使用者の意見を吸い上げ改善を行なっていること から、「適合」とした。

\section{3 国際規格を踏まえた課題と今後の方向性}

本規格をもとに、西口現地本部等の活動の検証を行うことで、既往の取り組みでは顕在化しなかった 課題についても明確にすることができた。今後は、今回の検証結果を活用して改善を図ることで、西口 地域のエリア防災の実効性をより高めるとともに、標準化を図ることが出来ると考えられる。本規格に よる検証を中心に、2013年度訓練結果も含め、西口現地本部の活動における主な課題と今後の取組みの 方向性を次に示す。

\section{(1)西口現地本部における情報の取扱について}

危機対応時の情報の取扱については、本規格が求めるレベルに対して乘離している事項が多く、具体 的な要求事項を参考に改善を図り、明確な情報の取り扱いルールや帳票を定め、今後の訓練を通じて検 証を行なう必要がある。

\section{(2)西口現地本部の機能と階層別の体制について}

危機対応時においては、西口現地本部が西口地域の防災活動における意思決定機関となると同時に、 関係者との連携・調整の場となるが、現時点ではそれぞれの活動は明確には区分されていない。現在の 西口現地本部の活動内容は、情報の収集・提供の他に、地域の資源の調整(応急救護活動、建物安全確認 活動等を含む)、滞留者等の避難誘導の方針決定等の多岐にわたっている。今後はこれらを階層別に整理 するとともに、それぞれのレベルの指揮者に与える役割・権限・責任を明確にする必要がある。その際 
には、ICS(インシデントコマンドシステム)の考え方を導入した体制の見直しも有効であると考えられる。

\section{(3)西口地域における関係者の連携について}

現地本部運営マニュアルは整備されているが、危機対応時に関係者が共有する目的や役割分担、また その階層構造等については明確に示されていない。地域内の複数の組織の協力・連携による活動を円滑 に進めるには、共通の目標を定めることが不可欠である。また関係各組織の指揮・統制プロセスにも、 西口現地本部を連携の場として組み込むよう働きかける必要がある。

\section{(4)西口地域における関係者の関与の仕組みについて}

西口地域では、セミナー・訓練等の活動内容の企画・実施・検証・普及や、関係者の間の調整等を部 会や幹事会において図る仕組みが機能している。今後も改善を行いながら継続的にこれらの活動を実施 することで、西口地域の事業者等の連携による地域防災の実効性向上を図る必要がある。

\section{4. おわりに}

新宿駅西口地域においては都市再生安全確保計画が策定され、今後は同計画に沿った様々なエリア防 災の取組みが実施されると考えられる。特に、災害時に必要となる対応については、現地本部が重要な 役割を果たすことになる。本報では、西口地域を先進的なモデルケースと位置づけて、現地本部の活動 に着目し、その機能や役割等を地域連携による訓練や危機対応に関する国際規格との比較という手法で 検証した。

国際規格(ISO22320)は、多様な災害対応機関（消防・警察・軍・国・自治体など）が災害時に円滑な 連携を可能にするための命令指揮系統の標準化を目的とした規格である。一方、西口現地本部は地域内 の関連機関間の情報共有を目的としたボランティア活動に依存した組織であり、災害対応時の指揮命令 系統や責任の所在、関連機関の連携の在り方などが明瞭ではなかった。今後、首都直下地震などによる 深刻な災害に備え、新宿駅周辺地域のような中心市街地での組織間連携による適切な対応行動を可能と するため、現地本部の役割及び機能については、本報で得られた課題や対応の方向性をもとにより充実 をはかる必要がある。なお2013年度訓練では、現地対策本部が発災後速やかに立ち上がったことを前提 として訓練が行われたが、要員参集及び現地本部の立ち上げに関する訓練等を通じた検証も重要な課題 のひとつとして認識している。

また、国際規格との比較により現状の危機対応活動を評価する手法についても、今まで顕在化しなか った課題が浮かび上がるなど一定の有用性が確認できた。地域連携による円滑なエリア防災活動にあた っては、関係する組織間での対応の標準化が重要となる、今後は個別組織の災害対応活動の検証におい ても本規格を参照し、標準化による利点を明確にするとともに、各組織への普及促進の取組みが必要と なる。なお、現地本部の活動に留まらず、都市再生安全確保計画に基づく地域防災を構成する活動全般 について、同様の手法により課題を抽出し継続的な改善に取り組む必要がある。

最後に、2013年度訓練にもとづく評価において「本規格適用外」とした事項のうち訓練想定の都合に より顕在化しなかった事項もある、これらについては今後実施する訓練の企画時に考慮し、多角的な検 証を行う必要がある。「適用外」及び「不適合」とした事項についても、規格そのものが、新宿駅周辺 の状況や地域事業者のゆるやかな連携により運営される組織に適していない可能性もある、新宿駅周辺 地域の現地本部之同様の取り組みは他の地域でも行われているため、将来的には同規格をもとに同様の 取り組みにより適した「規格」のあるべき姿についても提案したい。

\section{謝 辞}

都市再生安全確保計画の作成及び地域連携による訓練等は新宿区の委託業務として行った。また、本 研究を進めるにあたっては、文部科学省の「都市の脆弱性が引き起こす激甚災害の軽減化プロジェクト」 の研究助成を受けた。本論文作成にあたり、一般社団法人レジリエンス協会代表理事黄野吉博氏よりア ドバイスを受けた。最後に、西口地域における訓練は新宿駅周辺防災対策協議会が主催して実施したが、 
訓練の企画・実施にあたって多大な協力を頂いた同協議会西口部会幹事会員および訓練に参加した西口 地域の各事業者・団体、工学院大学建築学部の学生の皆様及び新宿区区長室危機管理課の皆様に深く感 謝の意を表する。

付録

表 2 IS022320 : 2011要求事項への適合評価結果

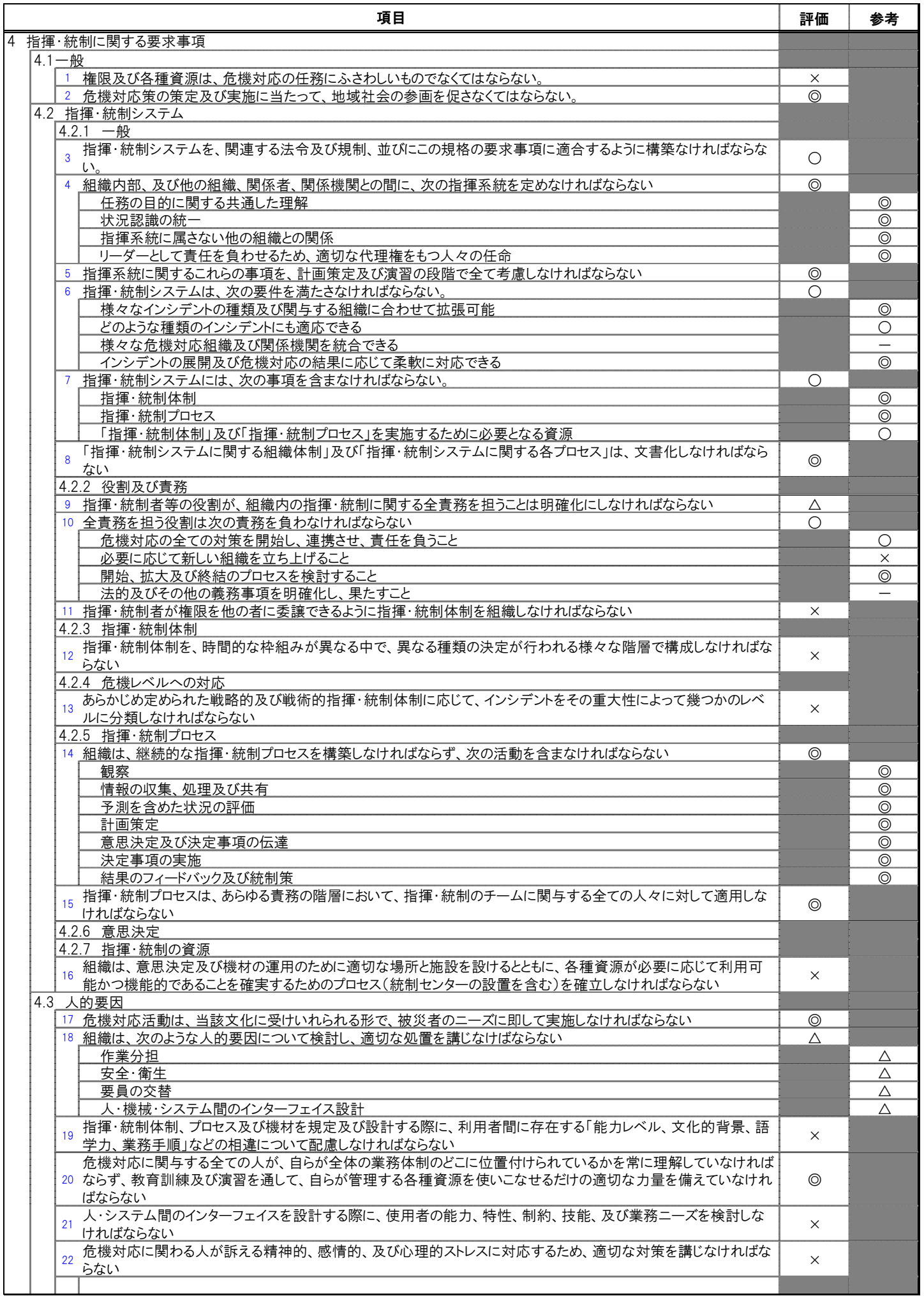




\begin{tabular}{|c|c|c|c|}
\hline \multicolumn{2}{|r|}{ 項目 } & 評価 & 参考 \\
\hline \multirow{4}{*}{\multicolumn{4}{|c|}{$\begin{array}{l}5 \text { 活動情報に関する要求事項 } \\
\begin{array}{|l}5.1 \text { - 般 } \\
5.2 \text { 活動情報提供プロセス } \\
5.2 .1 \text { - 般 }\end{array}\end{array}$}} \\
\hline & & & \\
\hline & & & \\
\hline & & & \\
\hline & \multicolumn{3}{|l|}{23 組織は、活動情報を提供する継続的プロセスを確立しなければならない。これには次の活動を含める。 } \\
\hline & 計画策定及び指示 & & (0) \\
\hline & 情報収集 & & (0) \\
\hline & 処理及び利用 & & (2) \\
\hline & 分析及び作成 & & (2) \\
\hline & 発信及び統合 & & () \\
\hline & 評価及びフィードバック & & () \\
\hline & 5.2 .2 計画策定及び指示 & & (0) \\
\hline & \multicolumn{3}{|l|}{24 活動情報は、指揮·統制プロセスの一部として計画し、準備しなければならず、次の活動を含まなけれなならない } \\
\hline & 危機対応業務を実施するための指示及び達成目標の提示 & & $x$ \\
\hline & 効率的な意思決定のための、主要な問題の特定 & & $x$ \\
\hline & 収集方法及び成果物に関する指針も含めた情報収集計画の策定 & & $x$ \\
\hline & 情報の保管、利用、アクセス権、及び制限に関する計画策定(データベースの設計、データ様式、通信手段など) & & $\times$ \\
\hline & 関係組織がもつ情報ニーズの確認 & & $x$ \\
\hline & 必要とされる情報に関する時間的制約の確認 & & $x$ \\
\hline & 発信に関する要求事項及び手順の決定（技術的及び非技術的） & & $x$ \\
\hline & 活動情報の処理に関わる人材配置計画の策定 & & $x$ \\
\hline & 情報処理装置及びその操作管理に関する計画の策定 & & $x$ \\
\hline & \multicolumn{3}{|l|}{5.2 .3 情報収集 } \\
\hline & \multicolumn{3}{|l|}{25 情報収集には、次の活動を含めなければならない } \\
\hline & \multicolumn{3}{|l|}{ 入手可能な情報源の確認 } \\
\hline & 情報の取得 & & (0) \\
\hline & 情報源及び入手時刻の特定も含め、入手した情報の登録及び記録 & & $x$ \\
\hline & \multicolumn{3}{|l|}{5.2 .4 情報の処理及び利用 } \\
\hline & \multicolumn{3}{|l|}{26 情報の処理及び利用には、次の活動を含めなければならない } \\
\hline & \multicolumn{3}{|l|}{ 効果的な発信をするために適切な書式への情報の適合 } \\
\hline & \multicolumn{3}{|l|}{ 情報の初期段階評価（妥当性及びその情報源の信頼性の評価） } \\
\hline & 無用、無関係、及び不正確な情報の排除 & & $x$ \\
\hline & \multicolumn{3}{|l|}{ 情報発信レベルの明示(機密性のレベルも含む。) } \\
\hline & \multirow{2}{*}{\multicolumn{3}{|c|}{$\begin{aligned} & \quad \text { 情報の信憑性の評価 } \\
& 5.2 .5 \text { 情報の分析及び作成 }\end{aligned}$}} \\
\hline & & & \\
\hline & \multicolumn{3}{|l|}{27 情報の分析及び作成のアウトプットは、指揮·統制者の優先要求事項又は情報提供の依頼を満さなければならない } \\
\hline & \multicolumn{3}{|l|}{28 情報の分析及び作成では、次の活動を含めなければならない } \\
\hline & 情報の改訂 & & (a) \\
\hline & 情報の優先順位付け及び分類 & & $x$ \\
\hline & 情報の照合、組立及び合成 & & $x$ \\
\hline & リスクの特定及びリスク分析 & & $x$ \\
\hline & 予想される結果の推定及び傾向の推論 & & $\triangle$ \\
\hline & 提案、推奨事項、報告、及びその他の情報処理アウトプットの作成 & & $\times$ \\
\hline & 5.2 .6 情報の発信及び統合 & & \\
\hline & 29 情報の発信及び統合に際しては、次の活動を実施しなければならない & $\triangle$ & \\
\hline & 特定の要求事項(技術的及び／又は非技術的)に準拠した発信 & & $x$ \\
\hline & 手順を確立し、文書化し、活動情報の利用者全てが閲覧できる情報にする & & 0 \\
\hline & 利用者がもつ状況認識へ組込み & & $x$ \\
\hline & 5.2 .7 評価及びフィードバック & & \\
\hline & $\begin{array}{l}30 \text { 組織ば、活動情報を生み出す各活動がうまく実行されていることを確認するため、あらゆる階層で評価を行なわなけ } \\
\text { ればならい }\end{array}$ & $\times$ & \\
\hline & 5.3 活動情報提供プロセスの評価基準 & & \\
\hline & 31 組織は、活動情報提供プロセスの中で、次の評価基準を確実に満たすように検討しなくてはならない & $\times$ & \\
\hline & 品質 & & \\
\hline & 全体的な見通し & & \\
\hline & 計画活動の同期 & & \\
\hline & 完全性 & & \\
\hline & 連携及び協力 & & \\
\hline & 優先順位付け & & \\
\hline & 予測 & & \\
\hline & 即応性 & & \\
\hline & 協働 & & \\
\hline & 融合 & & \\
\hline
\end{tabular}




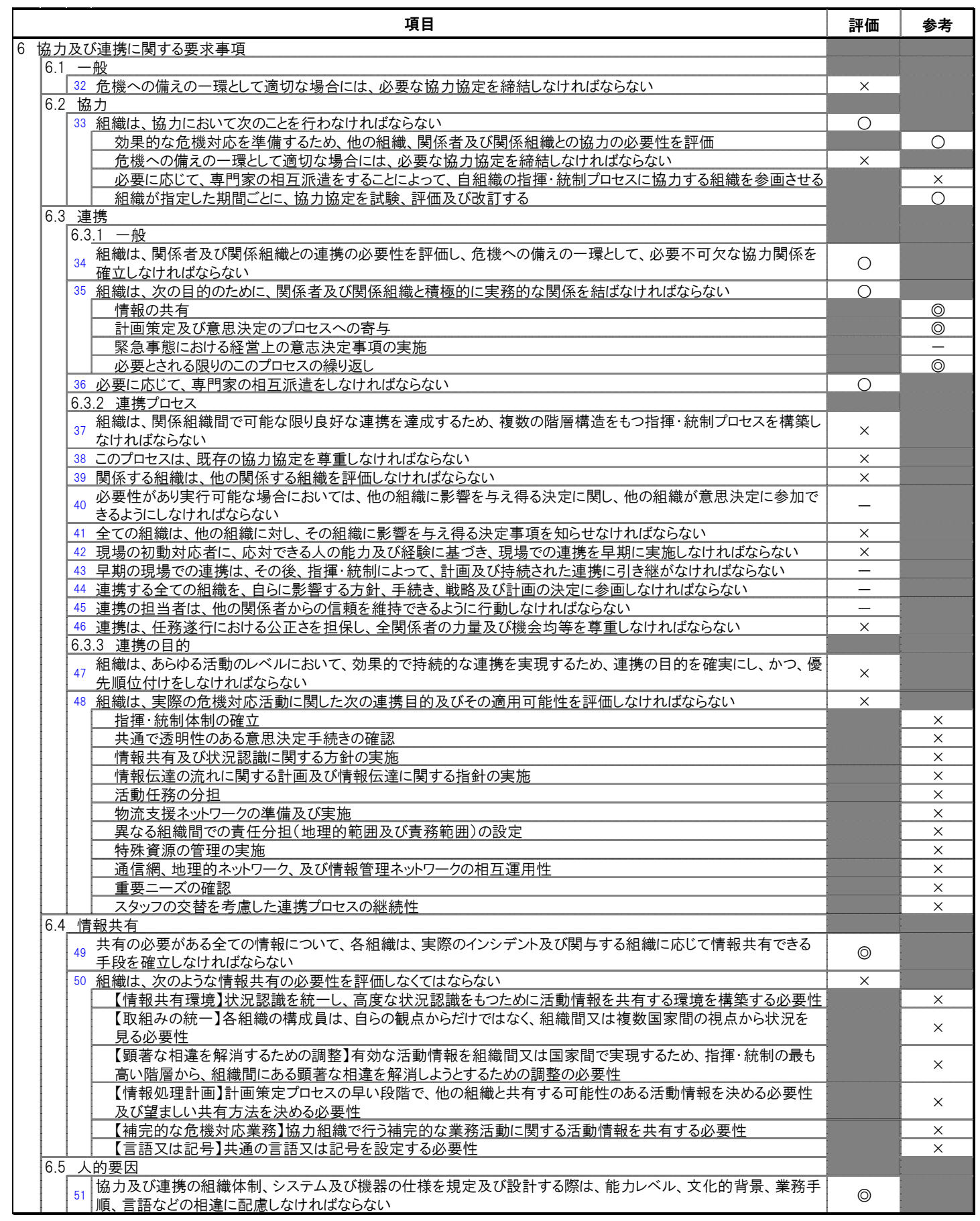




\section{参考文献}

1)新宿区 : 新宿駅西口地域都市再生安全確保計画策定基礎調查業務委託報告書、2013年.

2)西川智: 企業防災からBCP、そして地域毎のBCP協力へ、第13回日本地震工学シンポジウム、2010年、 ROMBUNNO.OS5-SAT-PM(OS5)-1.

3)村上正浩 : 新宿駅周辺地域におけるエリア防災の取り組み その 2 : 都市再生安全確保計画と今後の課 題、公開研究会「大地震から巨大都市（首都）をどう守るか-東日本大震災の経験を踏まえた建物・まち の対策-」、2013年、pp.49-56.

4) 村上正浩、久田嘉章 : 大規模ターミナル駅周辺の高度利用市街地における駅周辺滞留者対策・救急災 害医療対策に関する研究、第13回日本地震工学シンポジウム、2010年、ROMBUNNO.OS5-SAT-PM(OS5)-6. 5)新藤淳、平本達也、村上正浩、久田嘉章 : 東日本大震災時における事業者の行動について新宿駅西口 地域を対象としたアンケート調查より、日本地震工学会論文集第12巻、第4号(特集号)、2012年、pp.288-307 6)児島正 : 大学と地域社会との協働による社会的課題の解決を目指して-新宿新都心の防災まちづくりの 実践から-、第四紀研究第50巻第5号、2011年、pp259-264.

7)Y.Masuzawa,Y.Hisada,M.Murakami,J.Shindo,M.Miyamura,H.Suwa,S.Tanaka,K.Mizukoshi,Y.Nakajima:Practic e on an Education and Training Program to Development of Response Literacy to Earthquake Disaster in a Central Business District in Japan,Journal of Disaster Research, Vol.9, No2, 2014,pp. 216-234.

8)内閣府 : 都市再生安全確保計画制度等の概要(平成27年4月) https://www.kantei.go.jp/jp/singi/tiiki/toshisaisei/yuushikisya/anzenkakuho/pdf/seido_gaiyou.pdf . (参照 2016-03-03)

9)工学院大学 : 新宿駅西口地域地震防災訓練報告書、http://kouzou.cc.kogakuin.ac.jp/open/Shinjuku/ (参照 2015-04-07)

10)新宿区 : 新宿駅西口地域都市再生安全確保計画策定基礎調查業務委託報告書、2013年.

11)新宿駅周辺都市再生緊急整備協議会、新宿駅周辺地域都市再生安全確保計画（H26.3.27作成）

http://www.toshiseibi.metro.tokyo.jp/seisaku/toshisaisei/pdf/keikaku03.pdf. (参照 2015-04-07)

12)林春男、危機対応標準化研究会編著 : 世界に通じる危機対応 ISO22320(JIS Q 22320)社会セキュリテ イ-緊急事態管理-危機対応に関寸る要求事項 解説、日本規格協会、2014年.

（受理：2015年4月28日）

（掲載決定：2016年3月18日） 


\title{
Study on Emergency response by regional alliances and standardization in the Central Business Area around Shinjuku Station
}

\author{
SHINDO Jun ${ }^{1)}$, MURAKAMI Masahiro ${ }^{2)}$ and HISADA Yoshiaki ${ }^{3)}$ \\ 1) Sompo Japan Nipponkoa Risk Management Inc., M. Eng. \\ 2) School of Architecture, Department of Urban Design and Planning, Kogakuin University, Dr. Eng. \\ 3) School of Architecture, Department of Urban Design and Planning, Kogakuin University, Dr. Eng.
}

\begin{abstract}
In Urban Renaissance Safety Security Plan in Shinjuku-Nishiguchi region, Nishiguchi local headquarters plays an important role. In this paper, the role and functions of the local headquarters, were subjected to verification by comparing international standards(ISO22320) and drill. The verification in this study enabled to clarify the direction of future challenges and order to promote the area disaster prevention activities based on Urban Renaissance Safety Security Plan.
\end{abstract}

Keywords: Regional alliances, Area Disaster Management, Earthquake disaster prevention drill, ISO22320, Urban Renaissance Safety Security Plan 